\title{
Developing an Interactive University Orientation App: Potential Users' Feedback
}

\author{
https://doi.org/10.3991/ijim.v15i22.24523 \\ Radzuwan Ab. Rashid ${ }^{1}$, Nagaletchimee Annamalai ${ }^{2(凶)}$, Hadeel Saed ${ }^{3}$, \\ Baderaddin Yassin ${ }^{4}$, Omar Ali Al-Smadi ${ }^{5}$ \\ ${ }^{1}$ Universiti Sultan Zainal Abidin, Kuala Terengganu, Malaysia \\ ${ }^{2}$ School of Distance Education, Universiti Sains Malaysia, Penang, Malaysia \\ ${ }^{3}$ Applied Science Private University, Amman, Jordan \\ ${ }^{4}$ Al-Ghad International Colleges for Applied Medical Sciences, Riyadh, Saudi Arabia \\ ${ }^{5}$ University of Ha'il, Hail, Saudi Arabia \\ naga@usm.my
}

\begin{abstract}
The use of apps has become increasingly common in higher institutions and often linked with the needs of the current generation. This qualitative study investigates the perception of undergraduate students at a university in Malaysia as part of a need analysis to develop a university orientation app. Fifteen participants were interviewed and the findings suggest that the participants have positive perception of having the app. The positive perception is mainly based on the needs to navigate around the campus where the apps will help to make the navigation easier and effective by serving as 'one-stop information center'. In addition to the navigation purpose, the potential users request for gamification elements to keep them interested in using the app. This paper concludes that an appealing orientation app for the students should expose them to the university surrounding and at the same time contain gamification elements.
\end{abstract}

Keywords - smartphone apps, higher institution, gamification, orientation app

\section{Introduction}

Orientation week is an important event to start a successful transition and integration of campus life with rich experience. For these reasons, it is pertinent that the university welcomes the students most memorably. Activities should be planned effectively for students to receive materials, information, services, and entirely ready to kick start their university life. The difficulties of managing the orientation week for university students are mainly related to managing limited time with robust information, uncontrolled space, and faculty collaboration. Since most students are fresh from high schools, there is a need to motivate and reduce their anxiety in a short period.

Learning spaces are changing for a number of reasons [1]. First, students are well connected with technology, and forcing them to stay away from technology tools contradicts with the way they lead their lives. Second, information is ubiquitous and readily accessible. Their connectivity of smartphones enables them to access information 
in split seconds. Third, the way students think has changed. They are more interested in how to find information rather than recalling the information itself. In other words, students' cognition is involving. Hence, information tends to revolve around them. For these reasons, it is difficult to motivate students to learn with a traditional approach $[2,14,15]$. There is a need to do something different to reach the current students. Thus, the researchers in this study intend to address these challenges by designing an orientation app for a single institution in Malaysia. It can be argued that designing an app is not a simple task. A great deal of consideration should be given before it is developed. The enablers and barriers of an orientation app should be identified before embarking on the development of the app.

The current study was undertaken with three objectives. Firstly, to study what are the features that should be integrated into an orientation app. Secondly, to investigate students' perception on the use of the orientation app. Thirdly, to investigate students' perception when gamification is integrated into the orientation app. The findings of this study will help the researchers to design an interactive orientation app named Palm- Orienter.

\section{$2 \quad$ Literature review}

The current generation is raised in a technologically savvy environment. Millennials are children who are born between 1980-1994 and Gen Z are born between 1995-2015. They are heavy uses of technologies and crave for learning that is individualized, immediate, exciting, engaging, technologically advanced, and visually based. Generation $Z$ desires convenience and immediacy. As highlighted by [3], four characteristics of Gen Z: a) an interest in new technologies, b) an insistence on ease of use, c) a desire to feel safe, and d) a desire to temporarily escape the realities they face. Their technology habits lead them to have a limited attention span, get bored easily, experience monotony, and repetition.

The use of smartphones is one of the preferred digital devices for Gen Z. Smartphones are not restricted to only making calls and texting. Their social activities are also connected with social websites such as Facebook, Instagram and Twitter. With Internet access, they have been used for interpersonal communication, acquire knowledge and entertainment $[4,5]$. Mobile learning such as smartphones is pervasive and has the potential to enhance learners' engagement across "collaborative, contextual, constructionist and constructivist learning environments" [6, p.2]. In addition to this, smartphones can improve the productivity of individuals and increase the efficiency of teamwork [7]. As smartphones are used in various aspects of daily life, they appear to be creating a new culture [2]. The term nomophobia has been coined for users who are not willing to detach from their phones. Previous studies have highlighted whether smartphone attachment is because of the device itself or the affordances of the device $[8,9,10]$. For students, the use of smartphones and multitasking during class appears to be a norm despite the growing concerns about the detrimental consequences [11].

Many higher institutions are considering smartphones as a learning aid since the digital natives are very attached to smartphones [5]. Bring Your Own Device (BYOD) such as handphones, reduces institution costs, and develops new pedagogical 
practices. BYOD enables mobility and allows the users not to be confined to activities in the classroom. Therefore, it provides the opportunity for learning to evolve from e-learning to ubiquitous learning [12]. Learning materials can be accessed from anywhere without any time and space constraints.

\section{$3 \quad$ Methodology}

This study employed a qualitative case study to investigate 15 undergraduate students' perceptions in developing an orientation for University PP (pseudonym). The 15 participants are from School of Computer Sciences, Education, Management, and Biology and they have experienced the traditional orientation. The qualitative study assists the researchers to study the phenomena in its natural setting and make sense of how the findings will guide in designing the app. There were eight males and seven female participants. The average age of the participants was 23.5. All participants belong to Millennials and Gen Z generations. They are born after 1982. Telephone interviews were conducted since this study was conducted during the COVID-19 pandemic. Interviews were recorded and transcribed verbatim. Thematic Analysis by [13] was considered to identify, analyses, interpret, and report the open-ended questions. Six steps thematic analysis: 1) becoming familiar with the data and transcribing all data; 2) generating codes; 3) classifying codes into themes; 4) reviewing and refining themes; 5) concisely defining and naming themes; 6) producing a report from the emerging themes which is descriptive, analytical and argumentative narrative. Direct quotations from the participants were included to explain key themes.

The interview transcripts were coded by two experts in qualitative research. Member checks and peer debriefing ensured the valid information of the qualitative data. The interview transcripts were mailed to participants and were requested for edits and additions if there is a need to do so. Peer debriefing with the coders involved justification and verification of themes.

\section{$4 \quad$ Findings}

\subsection{Features to be included in the orientation app}

The dominant theme is an emphasis on the navigation around the campus. The firstyear students will definitely have difficulties in figuring out the location of the building in the campus. Therefore, the geolocation navigation services will be a great help. The campus navigation should not only display the university as a whole, but they should label significant buildings, landmarks, provide indoor floor plans, and guide students when they are heading the wrong way. Participants highlighted that smartphones are truly pervasive and designing an app will be a wise idea. They mentioned that they prefer to venture to the places at the campus independently and at their own pace. All they need is the location of the buildings and they can explore into the campus successfully. One of the participants highlighted that "the app needs to guide us to point to the lecture halls, sports activities café, and hostels" (P9). Similarly, another participant 
highlighted "we have an app called' Survival kit'but it is not helpful and not that accurate. We need a good app. It needs to indicate the direction. Since the buildings in our university are labeled with alphabets, it clearly needs to indicate where is H22, H23 etc.". (P4).

There were students who suggested to include cafes. P1 elaborated the "menus for each café is needed so that they will know where to go for food. I would like to have a 'waze' to direct me to the cafes." The app should also have "a column for frequently asked questions FAQ such as what time are students supposed to be in the hostel. Rules of the university" (P2). Also, "the app should allow us to submit the offer letter, receipts, and medical report $(\mathrm{P} 8)$. Most of the interviewees also believe that the "orientation schedule should be uploaded for a smooth registration" (P11). There must be " $a$ section for us to upload their documents, personal details" (P6). A "column for clubs and activities, getting stickers for your cars, and online payments” (P11).

All in all, participants suggested an app that will be "one-stop information rather than asking so many people for information" (P10). Interestingly, one of the interviewees pointed out that sometimes the information conveyed by the seniors might not be accurate because "things change every year and the seniors might not be aware of the latest changes.” (P2).

\subsection{Elements of gamification in an orientation app}

All the participants agreed that the gamification approach motivates the students to complete the task assigned to them during the orientation week. They agreed the use of points, leader boards, and badges will obviously motivate them into action and they will strive for further improvement. One student mentioned that "games will motivate them, otherwise they will not be serious. Students expect something in return." (P5).

The following idea was also communicated:

"Reward system is good. They will be motivated. When they travel to the correct location and complete the task given, they should be given points. Maybe the university should implement students to collect point My Continuous Development Point (CSD). Students with high points are allowed to stay in the hostel. At the same time, they use these points when they are out for industrial training. These points show whether one is active or not during campus time." (P6).

Another participant said that publicity would drive the new students to strive harder to reach a specific target. One of the participants commented:

"Competition will help them to complete the task. otherwise, they will procrastinate. It is also good to connect to social media because people prefer publicity and they will perform better".

The participants see social media as a positive influence for the students to consider the task assigned to them during orientation week. For example, "if you put it in the social media other students will know about the new students. During COVID-19 the seniors will not be able to meet the new students, by putting up the events in social 
media they will know the new students. Also, points are a good idea, they [students] will be competitive and complete the task especially if the group task is based on faculties"

\section{Discussion}

Participants have requested to include features that will allow them to go around the campus independently. For example, locations, schedule cafes, faculty information, campus rules, frequently asked questions, orientation schedule, activities clubs, etc. They also requested information to be uploaded to save cost and time will be spent wisely by the university. As described [12] BYOD has reduced institutions' costs and developed new pedagogical practices. Technology has given young people an unprecedented degree of connectivity among themselves therefore they feel that time and space can be saved with an app. The finding is consistent [16] that functionality and convenience features of the smartphones are the main attributes for smartphones to appear attractive to users.

The findings also indicate that the current generation (Millenials \& Gen Z) interact differently for information. They prefer texting rather than having a face to face interaction. They have strong desires to learn and gain information themselves. They are always connected. They constantly evaluate unprecedented amounts of information. For them, 'the self' is a place to experiment, test, and learn. They do not want to experience the traditional orientation which in their perception is boring and hectic. In addition to this, they feel that the information given by the seniors can be misleading at times. Similarly, the findings indicated the four characteristics of Gen Z: who are very much interested in technologies, insistence on ease of use, desire to feel safe, and to escape from the realities they face $[13,16]$.

When asked about the integration of Facebook and other social media platforms, the interviewees response was positive. Participants commented that gamification and social media will be a motivating factor. Such idea is in line with the findings of [14] that gamification and integration with social media foster users' engagement and encourage them to complete the task assigned to them.

\section{Conclusion}

The study reveals that an orientation app would be a worthwhile attempt and able to cater to the needs of the technology-savvy students who are always connected. The main reason supporting the need for the orientation app is that it will serve as a 'onestop information center' which can be easily accessed by students hence making their navigation around campus much easier and effective. Nevertheless, an appealing orientation app should also contain gamification elements for the sustainability of its use. With limitless access to information at students' fingertips via smartphones, the traditional style of university orientation is obsolete and the university has to move on to technology-enhanced university orientation. 


\section{$7 \quad$ References}

[1] Eldokhny, A. A., \& Drwish, A. M. (2021). Effectiveness of augmented reality in online distance learning at the time of the COVID-19 pandemic. International Journal of Emerging Technologies in Learning, 16(9): 198-218. https://doi.org/10.3991/ijet.v16i09.17895

[2] Lee, J. J., \& Hammer, J. (2011). Gamification in education: What, how, why bother? Academic Exchange Quarterly, 15(2): 1-5.

[3] Persada, S., Ivanovski, J., Miraja, B., Nadlifatin, R., Mufidah, I., Chin, J., \& Redi, A. (2020). Investigating generation z'intention to use learners' generated content for learning activity: a theory of planned behavior approach. International Journal of Emerging Technologies in Learning, 15(4): 179-194. https://doi.org/10.3991/ijet.v15i04.11665

[4] Ozkan, M., \& Solmaz, B. (2015). Mobile addiction of generation z and its effects on their social lifes:(An application among university students in the 18-23 age group). Procedia-Social and Behavioral Sciences, 205: 92-98. https://doi.org/10.1016/j.sbspro.2015.09.027

[5] Anshari, M., Almunawar, M. N., Shahrill, M., Wicaksono, D. K., \& Huda, M. (2017). Smartphones usage in the classrooms: Learning aid or interference? Education and Information Technologies, 22(6): 3063-3079. https://doi.org/10.1007/s10639-017-9572-7

[6] Herrington, J., Herrington, A., Mantei, J., Olney, I. \& Ferry, B. (2009). Using mobile technologies to develop new ways of teaching and learning. In J. Herrington, A. Herrington, J. Mantei, I. Olney \& B. Ferry (Eds.), New technologies, new pedagogies: Mobile learning in higher education (pp.1-14). University of Wollongong, Australia.

[7] Elhai, J. D., Levine, J. C., Alghraibeh, A. M., Alafnan, A. A., Aldraiweesh, A. A., \& Hall, B. J. (2018). Fear of missing out: Testing relationships with negative affectivity, online social engagement, and problematic smartphone use. Computers in Human Behavior, 89, 289-298. https://doi.org/10.1016/j.chb.2018.08.020

[8] Abugohar, M. A., Yunus, K., \& Rashid, R. A. (2019). Smartphone applications as a teaching technique for enhancing tertiary learners' speaking skills: perceptions and practices. International Journal of Emerging Technologies in Learning, 14(9):74-92. https://doi.org/10.3991/ ijet.v14i09.10375

[9] Holte, A. J., \& Ferraro, F. R. (2018). Tethered to texting: Reliance on texting and emotional attachment to cell phones. Current Psychology, 1-8. https://doi.org/10.1007/ s12144-018-0037-y

[10] Trub, L., \& Barbot, B. (2016). The paradox of phone attachment: Development and validation of the Young Adult Attachment to Phone Scale (YAPS). Computers in Human Behavior, 64, 663-672. https://doi.org/10.1016/j.chb.2016.07.050

[11] Levine, L. E., Waite, B. M., \& Bowman, L. L. (2012). Mobile media use, multitasking and distractibility. International Journal of Cyber Behavior, Psychology and Learning (IJCBPL), 2(3), 15-29. https://doi.org/10.4018/ijcbpl.2012070102

[12] Liu, G. Z., \& Hwang, G. J. (2010). A key step to understanding paradigm shifts in e-learning: Towards context-aware ubiquitous learning. British Journal of Educational Technology, 41(2): E1-E9. https://doi.org/10.1111/j.1467-8535.2009.00976.x

[13] Braun, V., \& Clarke, V. (2006). Using thematic analysis in psychology. Qualitative Research in Psychology, 3(2), 77-101. https://doi.org/10.1191/1478088706qp063oa

[14] Bichi, A. A., Embong, R., \& Rashid, R. A. (2017). Nigerian postgraduate students' attitude and perceived competence in using ICT resources for research purpose. Journal of Nusantara Studies, 2(2), 224-230. https://doi.org/10.24200/jonus.vol2iss2pp224-230 
[15] Rashid, R.A. (2016). Responding to 'nurturing global collaboration and networked learning in higher education'. Research in Learning Technology, 24, 1-3. https://doi.org/10.3402/rlt. v24.31485

[16] Had, M. Z. C., \& Rashid, R. A. (2019). A review of digital skills of malaysian english language teachers. International Journal of Emerging Technologies in Learning, 14(2), 139-145. https://doi.org/10.3991/ijet.v14i02.8732

\section{Authors}

Radzuwan Ab. Rashid is an Associate Professor of Education and Discourse Studies in the Faculty of Languages and Communication, Universiti Sultan Zainal Abidin, Malaysia. He can be reached at radzuwanrashid@unisza.edu.my

Nagaletchimee Annamalai is a senior lecturer in the School of Distance Education, Universiti Sains Malaysia. She can be reached at naga@usm.my

Hadeel Saed is an Associate Professor at the Applied Science Private University, Jordan. She can be reached at h_alsaed@asu.edu.jo

Baderaddin Yassin is an Assistant Professor at Al-Ghad International Colleges for Applied Medical Sciences, Riyadh, Saudi Arabia. He can be reached at Byassin@gc.edu.sa

Omar Ali Al-Smadi is an Assistant Professor at the University of Ha'il, Hail, Saudi Arabia. He can be reached at omarsmadi91@yahoo.com

Article submitted 2021-06-04. Resubmitted 2021-09-19. Final acceptance 2021-09-20. Final version published as submitted by the authors. 